\title{
Spinocerebellar ataxia type 38
}

INSERM

\section{Source}

INSERM. (1999). Orphanet: an online rare disease and orphan drug data base.

Spinocerebellar ataxia type 38. ORPHA:423296

Spinocerebellar ataxia type 38 (SCA38) is a subtype of autosomal dominant cerebellar ataxia type 3 characterized by the adult-onset (average age: 40 years) of truncal ataxia, gait disturbance and gaze-evoked nystagmus. The disease is slowly prog ressive with dysarthria and limb ataxia following. Additional manifestations include diplopia and axonal neuropathy. 